UDC 911.3: 913

DOI: 10.18413 /2408-9346-2015-1-4-3-10

Afanasiev O.E.

\title{
SOCIO-ECONOMIC RECREATIONAL AND TOURISM RESOURCES OF DEPENDENT TERRITORIES OF THE WORLD: EXPERIENCE OF ASSESSMENT
}

\author{
Doctor of Geographical Sciences, Professor of Department of Business Technologies in Tourism \\ and Hospitality, Russian State University of Tourism and Service \\ Glavnaya Str., Cherkizovo Village, Pushkin District, Moscow Region. 141221, Russia \\ E-mail: olafn_dp@mail.ru
}

\begin{abstract}
The article describes the experience of numerical score of socio-economic recreation and tourism resources of 30 dependent states and territories in the world. The choice of this specific category of countries as a spatial object of study - dependent and non-self-governing territories - is conditioned by modern trends of growth of consumer tourist services demand for the unique, specific, secure and high-standard destinations. Such areas often have significant recreational potential that is almost unknown to the Russian market of tour offers, and because of this - not in demand.

The study found that almost all of the analyzed dependent countries offer a wide range of tourist and entertainment services, where Anguilla, Aruba, Bermuda, Puerto Rico, French Polynesia have especially well-developed infrastructure. For comparative characteristic and numerical score of socioeconomic recreational and tourism resources of these countries the numerical score matrix is developed. It includes seven indicators, each of which is rated on a five-point grade scale. Following the results of the integrated assessment of tourism and recreational resources all analyzed dependent states and territories are grouped into five groups: 1) having the lowest characteristics of recreation and tourism resources (Wallis and Futuna, Niue, American Samoa, Pitcairn, Tokelau, Saint Pierre and Miquelon, Falkland Islands); 2) having a lower middle resource endowment (Cook Islands, Anguilla, Montserrat, Norfolk Island); 3) having an average resource endowment (Gibraltar, Ceuta and Melilla, Saint Helena, Turks and Caicos Islands, French Guiana); 4) having a medium-high resource endowment (British and US Virgin Islands, Cayman Islands, Martinique, Reunion, French Polynesia, Guam, New Caledonia); 5) having a high recreation and tourist resource endowment (Bermuda, former Netherlands Antilles, Aruba, Guadeloupe, Puerto Rico).

For a more objective assessment of endowment of recreational and tourism resources of dependent states and territories of the world it is also necessary to take into account the other types and categories of these resources. Nevertheless, the obtained results give overall representative characteristics of the tourism potential of main dependent states and territories worldwide, and the methodology itself is verifiable and for other similar entities of political map of the world.
\end{abstract}

Keywords: dependent states and territories of the world, recreational and tourism resources, numerical score of development recourses of tourism.

Афанасьев О.Е.

ОПЫТ ОЦЕНКИ СОЦИАЛЬНО-ЭКОНОМИЧЕСКИХ РЕКРЕАЦИОННЫХ И ТУРИСТСКИХ РЕСУРСОВ ЗАВИСИМЫХ ТЕРРИТОРИЙ МИРА

доктор географических наук, профессор кафедры бизнес-технологий в туризме и гостеприимстве, Российский государственный университет туризма и сервиса

ул. Главная, поселок Черкизово, Пушкинский район, Московская область, 141221, Россия

E-mail: olafn_dp@mail.ru

Аннотация. В статье представлен опыт балльной оценки социально-экономических рекреационно-туристских ресурсов 30 зависимых стран и территорий мира. Выбор в 
качестве территориального объекта исследований специфической категории стран зависимых и несамоуправляющихся территорий - обусловлен современными тенденциями роста спроса потребителей туристских услуг на уникальные, специфичные, безопасные и соответствующие высоким стандартам направления. Такие территории зачастую обладают существенным рекреационным потенциалом, который на российском рынке турпредложений практически неизвестен, а в силу этого - и не востребован.

В ходе исследования установлено, что почти во всех анализируемых зависимых странах мира предлагается большой спектр туристско-развлекательных услуг, среди которых особо развитой инфраструктурой отличаются Ангилья, Аруба, Бермудские о-ва, Пуэрто-Рико, Французская Полинезия. Для сравнительной характеристики и балльной оценки социально-экономических рекреационно-туристских ресурсов этих стран разработана матрица балльной оценки, включающая семь показателей, каждый из которых оценен по пятибалльной шкале. По итогам интегральной оценки туристско-рекреационных ресурсов все анализируемые зависимые страны и территории объединены в пять групп: 1) имеющие наинизшие характеристики обеспеченности рекреационно-туристскими ресурсами (о-ва Уоллис и Футуна, Ниуэ, Американское Самоа, Питкерн Токелау, Сен-Пьер и Микелон, Фолклендские о-ва); 2) имеющие средненизкую обеспеченность (о-ва Кука, Ангилья, Монтсеррат, Норфолк); 3) имеющие среднюю обеспеченность (Гибралтар, Сеута и Мелилья, о-ва Сент-Гелен, Теркс и Кайкос, регион Французская Гвиана); 4) имеющие средневысокую обеспеченность (Британские и Американские Виргинские о-ва, Каймановы о-ва, о. Мартиника, о. Реюньон, Французская Полинезия, о. Гуам, Новая Каледония); 5) имеющие высокую обеспеченность рекреационно-туристскими ресурсами (Бермудские о-ва, Нидерландские Антилы, о. Аруба, о. Гваделупа, о. Пуэрто-Рико).

Для более объективной оценки обеспеченности зависимых стран и территорий мира рекреационно-туристскими ресурсами необходимо учесть и иные виды и категории таких ресурсов. Тем не менее, полученные результаты дают в целом репрезентативную характеристику потенциала туристской сферы основных зависимых стран и территорий мира, а сама методика является верифицируемой и для других подобных субъектов политической карты мира.

Ключевые слова: зависимые страны и территории мира, рекреационно-туристские ресурсы, балльная оценка ресурсов развития туризма

The modern period of development of the world tourism industry is characterized by its high growth rates. Thus, according to the recently published annual report of World Travel and Tourism Council [12], the contribution of tourism to GDP in Europe at the end of 2014 was $9,2 \%$ and was higher than that of the automotive and chemical industries, banking, agriculture and the mining industry. In particular, the tourism industry has brought to the European economy $€ 1,8$ bln. ( $\$ 2,1$ trillion.), which is 2,6 times greater than the contribution of extractive industries (\$ 796 million.) and 1.8 times higher than the contribution to the regional GDP from the banking sector ( $\$ 1,2$ trillion.).

The trend of the last decade is that interest and demand of tourists to travel to the remotest corners of the globe that are attractive due to their identity, exotic and unique natural landscape significantly increased [4]. Traditional areas of mass tourism because of their significant congestion during peak seasons, and also due to a downward trend of «fashion» on them give way to areas characterized by fundamental uniqueness, originality, «newness», relative freshness, but at the same time these areas provide tourist services in accordance with the world standards and requirements. These many currently existing dependent states and territories are new tourist areas. The tourism potential of these areas is virtually unknown and almost not available on the market of tourism services in Russia. These areas can potentially make a weighty alternative to «hackneyed» mass routes for a relatively sophisticated Russian consumer.

Our research is concerned with the recreational and tourism resources of the dependent and non-selfgoverning territories of the world. Research subject peculiarities of the use of numerical score for it. Modern political map of the world covers more than 250 countries and territories. Of these, at the end of 2015, there are 17 depended and non-self-governing territories according to the classification of the United Nations, and about 100 under different approaches to 
their determination [2]. They all have different official political status, forms of dependence and selfgovernment, different level and basis of economic development. But more important is that such areas often have significant recreational potential, offer a comfortable environment for recreation, they are notable for guaranteed level of security. This is particularly important in the current conditions of an aggravation of the foreign policy situation in the world. Today, when a growing number of traditional tourist destinations in varying degrees are at the forefront of inter-civilizational conflicts and contradictions, demands from customers to ensure personal safety with the presence of the usual high standards of service increase dramatically. Many of the dependent states and territories that are small in size and that do not play any appreciable role in foreign policy in the world, situated in a comfortable climatic zones and do not have armed terrorist groups threatening health and lives of tourists comply with those conditions. These, and a number of other factors greatly increase the tourist and recreational attraction of the dependent and non-self-governing territories who deserve to find a representation in the Russian market of tourism offers.

The basic component of the tourism business is a complex of recreational and tourist resources (RTR) of a territory. The resource problems that consider essence and structure, strategy and tactics of the use of natural and socio-economic resources, not the least is the question of their identification, analysis and evaluation. Such scientists as A. Aleksandrova, A. Bejdyk, M. Birzhakov and others in one way or another had systematized methodological bases and had improved methods for assessing RTR [7].

Under RTR we understand natural objects and phenomena of natural, natural and human, and social origin, used for tourism, medical treatment, rehabilitation, which affect on the territorial organization of recreational activities, the formation of the recreational areas (centers), their specialization and cost-effectiveness; collection of natural, natural and technical, social and economic systems and their components, contributing to the refection and development of physical and spiritual forces of man, his ability to work in today's and future structure of the recreational needs and the technical and economic capacities that are used for direct and indirect consumption, provision of recreation and tourist, and health resort services [3].

There are various methods for assessment of natural geographic and socio-historical RTR. One of the interesting and more appropriate in terms of recreational complex analysis of the territory is the A. Bejdyk methods of RTR assessment allowing fact by fact to evaluate each of the components. In the structure of recreational resources two main components are identified: natural and socioeconomic (natural, historical and cultural resources of recreational activities). Characteristics of recreational resources include information about natural environment quality, area (or volume) for which the qualities are spread, the length of period, during which certain qualities take action, etc.

Recreation and tourism resources are peculiar not only for independent states; dependent territories of the world also have those. However, there is a big problem in the identification and characterization of these resources in the dependent states, due to the low availability of information about them. So it is almost impossible to find in the domestic market of tourist offers tourist maps of countries and territories, guides and reference books about them, information on infrastructure facilities and destinations, a stable image of these entities does not exist, represented by them tourist brands are not known [1]. Therefore, we propose the author's view on the principles, methodology and assessment features and characteristics of the recreational and tourism resources of dependent and non- self-governing territories. Having evaluated by components natural and socio-historical resources of these countries, it is possible to obtain an integrated numerical score of their recreational potential.

To assess the RTR we selected 30 dependent and non-self-governing countries:

a) 16 states, which are still covered by the UN Declaration on the Granting of Independence to Colonial Countries and Peoples (the «Declaration of Decolonization») dated 14.12.1960, that UN recognizes as colonies;

b) 14 states and territories, regardless of the current legal status (dependent territories, overseas territories, overseas departments, autonomous cities, self-governing communities, free associated states etc.), the ones that de facto represent the classical pieces of colonial empires, located at considerable distances from their mother countries.

The most important factor in the development of recreational activities in the dependent states is the economic and social one. It is responsible for the presence in these countries of a wide range of tourist services and infrastructure. For example, the dependent territories in the Caribbean Sea are among the most attractive tourist destinations. Welldeveloped hotel infrastructure, a high level of service, a variety of cultural, sports and recreational activities, many other components of socio-economic factors all this is typical for most dependent states in the world. Also, the majority of the dependent territories of the world have a very strong cultural and historical 
base, which is certainly the attractant for tourists from around the world.

In almost all analyzed dependent states a wide range of tourist and recreational services is offered (tab. 1) that reasonably prove the high level of development of active forms of tourism there.

Table 1

The range of active tourism services in the resorts of the dependent territories in the world (based on $[6,9,10]$ )

Спектр услуг активного туризма на курортах зависимых территорий мира (по материалам $[6,9,10])$

\begin{tabular}{|c|c|c|c|c|c|c|c|c|c|c|}
\hline Dependent territories & $\frac{4}{8}$ & 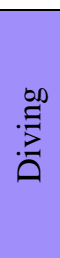 & 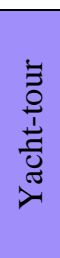 & 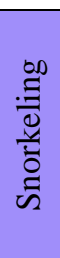 & 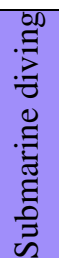 & 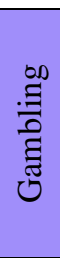 & 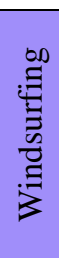 & 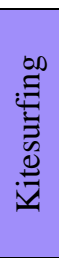 & 唁 & 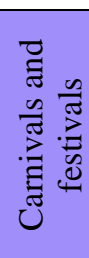 \\
\hline 1. American Samoa (U.S.) & - & + & - & + & + & - & - & - & - & + \\
\hline 2. Anguilla (U.K.) & - & + & + & + & + & - & - & - & - & + \\
\hline 3. Aruba (Neth.) & - & + & + & + & + & + & + & + & - & + \\
\hline 4. Bermuda (U.K.) & - & + & - & + & + & - & + & + & - & + \\
\hline 5. British Virgin Islands (U.K.) & - & + & - & - & - & - & - & - & - & + \\
\hline 6. Cayman Islands (U.K.) & 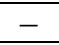 & + & 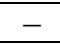 & + & + & 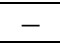 & 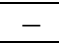 & 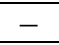 & 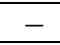 & + \\
\hline 7. Ceuta (Sp.) & - & - & - & - & - & - & - & - & - & - \\
\hline 8. Cook Islands (N.Z.) & - & + & + & + & + & - & - & - & $\begin{array}{cc}- \\
-\end{array}$ & + \\
\hline 9. Falkland Islands (U.K.) & - & - & - & - & - & - & - & - & - & + \\
\hline 10. French Guiana (Fr.) & - & + & - & - & - & - & + & + & - & - \\
\hline 11. French Polynesia (Fr.) & - & + & + & + & + & - & - & - & - & + \\
\hline 12. Gibraltar (U.K.) & - & + & + & - & - & - & - & - & + & - \\
\hline 13. Guadeloupe (Fr.) & - & + & + & + & - & - & - & - & - & + \\
\hline 14. Guam (U.S.) & + & + & $\begin{array}{ll}- \\
-\end{array}$ & + & + & $\begin{array}{ll}- \\
-\end{array}$ & + & - & $\begin{array}{lll}- & & \\
\end{array}$ & $\begin{array}{lll}- & & \\
\end{array}$ \\
\hline 15. Martinique (Fr.) & - & + & + & - & - & - & - & - & - & + \\
\hline 16. Melilla (Sp.) & - & - & - & - & - & - & - & - & - & - \\
\hline 17. Montserrat (U.K.) & - & - & - & - & - & - & - & - & - & + \\
\hline $\begin{array}{l}\text { 18. Neth. Antilles (Curaçao, Sint Maarten, Bonaire, } \\
\text { St. Eustatius and Saba) (Neth.) }\end{array}$ & - & + & - & - & - & + & - & - & - & + \\
\hline 19. New Caledonia (Fr.) & - & + & + & + & - & - & + & + & - & + \\
\hline 20. Niue (N.Z.) & - & + & - & + & + & - & - & - & - & - \\
\hline 21. Norfolk Island (Aust.) & - & + & + & - & - & - & - & - & - & - \\
\hline 22. Pitcairn Islands (U.K.) & - & + & + & - & - & - & - & - & - & - \\
\hline 23. Puerto Rico (U.S.) & - & + & - & - & - & + & + & + & - & + \\
\hline 24. Reunion (Fr.) & - & + & - & + & + & - & - & - & - & - \\
\hline $\begin{array}{l}\text { 25. Saint Helena, Ascension and Tristan da Cunha } \\
\text { (U.K.) }\end{array}$ & - & + & - & - & - & - & - & - & - & - \\
\hline 26. Saint Pierre and Miquelon (Fr.) & - & + & - & - & - & - & - & - & - & - \\
\hline 27. Tokelau (N.Z.) & - & + & - & + & - & - & - & - & - & - \\
\hline 28. Turks and Caicos Islands (U.K.) & - & + & + & - & + & + & - & - & - & - \\
\hline 29. United States Virgin Islands (U.S.) & - & + & + & - & + & - & - & - & - & + \\
\hline 30. Wallis and Futuna (Fr.) & - & + & - & - & + & - & - & - & - & - \\
\hline
\end{tabular}

Many resorts of dependent states offer a huge range of services and tourist attractions, among which Anguilla, Aruba, Bermuda, Puerto Rico, French Polynesia have especially well-developed infrastructure. These island countries possess a quite developed tourist infrastructure and are the worldfamous resorts. The most common tourist services in the analyzed dependent territories are diving and carnival performances. This is due to the unique natural environment and unique cultural traditions of the local people.
Over the past few decades in most of the analyzed dependent states a large number of first-class hotels have been built, new tourist areas have formed. The popularity of destinations, the level of development of its tourist industry can be measured by the number of hotel complexes, the number of tourists visiting this or that dependent state, income from tourism, produced annually by each individual country, and also presence of historical and cultural potential of interest for tourists. For comparative characteristics and assessment of indicated parameters of RTR of dependent states and territories, we have developed a matrix scoring (tab. 2). 
Matrix of numerical score of RTR of dependent states and territories

Table 2

Матрица балльной оценки РТР зависимых государств и территорий

\begin{tabular}{|c|c|c|c|c|c|c|}
\hline \multirow{2}{*}{\multicolumn{2}{|c|}{ Indicators and measurement units }} & \multicolumn{5}{|c|}{ Assessment conditions in balls } \\
\hline & & 5 & 4 & 3 & 2 & 1 \\
\hline \multicolumn{7}{|c|}{ Main statistical values of tourist industry development } \\
\hline A & Hotels evaluation, number of hotels & $>40$ & $40-31$ & $30-21$ & $20-10$ & $<10$ \\
\hline $\mathrm{B}$ & Tourist number, thousands a year & $>200$ & $200-100$ & $100-50$ & $50-10$ & $<10$ \\
\hline $\mathrm{C}$ & Tourism profit in USD & $>500$ & $500-100$ & $100-50$ & $50-10$ & $<10$ \\
\hline \multicolumn{7}{|c|}{ Cultural and historical potential } \\
\hline $\mathrm{D}$ & General number of museums of different purposes, units & $>8$ & $8-7$ & $6-5$ & $4-3$ & $2-1$ \\
\hline $\mathrm{E}$ & Number of cult (religious) architecture buildings, units & $>13$ & $13-10$ & $9-7$ & $6-4$ & $3-1$ \\
\hline $\mathrm{F}$ & Number of military and historical architecture buildings, units & $>4$ & 4 & 3 & 2 & 1 \\
\hline G & $\begin{array}{l}\text { Number of architectural monuments, } \\
(*) \text { presence of UNESCO monuments, units }\end{array}$ & $1 *$ & & 2 & & 1 \\
\hline
\end{tabular}

The results of the score about the indicated in the tab. 2 indicators are presented in tab. 3. Comparison of the analyzed dependent states on these parameters of RTR allows to clearly see the ratio of their socio-economic, cultural and historical prerequisites for tourism development.

Table 3

Assessment of RTR of dependent states and territories worldwide

Оценка РТР зависимых государств и территорий по всему миру

\begin{tabular}{|c|c|c|c|c|c|c|c|c|c|}
\hline \multirow[t]{2}{*}{ Dependent territories } & \multicolumn{7}{|c|}{ Assessment of indicators, balls } & \multirow{2}{*}{$\Sigma$ balls } & \multirow{2}{*}{$\begin{array}{c}\text { I, } \\
\text { ball }\end{array}$} \\
\hline & A & B & $\mathrm{C}$ & $\mathrm{D}$ & $\mathrm{E}$ & $\mathrm{F}$ & G & & \\
\hline 1. American Samoa (U.S.) & 1 & 2 & 1 & 1 & 1 & 0 & 0 & 6 & 1 \\
\hline 2. Anguilla (U.K.) & 1 & 2 & 3 & 1 & 1 & 0 & 0 & 8 & 2 \\
\hline 3. Aruba (Neth.) & 3 & 5 & 5 & 3 & 5 & 1 & 1 & 23 & 5 \\
\hline 4. Bermuda (U.K.) & 4 & 5 & 4 & 5 & 1 & 5 & 6 & 30 & 5 \\
\hline 5. British Virgin Islands (U.K.) & 2 & 5 & 4 & 1 & 1 & 3 & 0 & 16 & 4 \\
\hline 6. Cayman Islands (U.K.) & 2 & 5 & 5 & 1 & 1 & 2 & 0 & 16 & 4 \\
\hline 7. Ceuta (Sp.) & 1 & 3 & 2 & 2 & 2 & 1 & 0 & 11 & 3 \\
\hline 8. Cook Islands (N.Z.) & 2 & 3 & 2 & 1 & 1 & 0 & 0 & 9 & 2 \\
\hline 9. Falkland Islands (U.K.) & 1 & 2 & 1 & 1 & 1 & 0 & 0 & 6 & 1 \\
\hline 10. French Guiana (Fr.) & 1 & 3 & 2 & 2 & 1 & 2 & 0 & 11 & 3 \\
\hline 11. French Polynesia (Fr.) & 3 & 4 & 4 & 3 & 3 & 0 & 1 & 18 & 4 \\
\hline 12. Gibraltar (U.K.) & 2 & 5 & 5 & 1 & 1 & 1 & 0 & 15 & 3 \\
\hline 13. Guadeloupe (Fr.) & 4 & 5 & 5 & 4 & 2 & 4 & 0 & 24 & 5 \\
\hline 14. Guam (U.S.) & 1 & 5 & 5 & 1 & 1 & 0 & 3 & 16 & 4 \\
\hline 15. Martinique (Fr.) & 2 & 5 & 4 & 3 & 1 & 2 & 0 & 17 & 4 \\
\hline 16. Melilla (Sp.) & 2 & 3 & 2 & 1 & 1 & 2 & 0 & 11 & 3 \\
\hline 17. Montserrat (U.K.) & 1 & 2 & 2 & 1 & 1 & 2 & 0 & 9 & 2 \\
\hline $\begin{array}{l}\text { 18. Neth. Antilles (Curaçao, Sint Maarten, } \\
\text { Bonaire, St. Eustatius and Saba) (Neth.) }\end{array}$ & 4 & 5 & 5 & 1 & 1 & 1 & 5 & 22 & 5 \\
\hline 19. New Caledonia (Fr.) & 1 & 4 & 3 & 3 & 2 & 1 & 5 & 19 & 4 \\
\hline 20. Niue (N.Z.) & 1 & 1 & 1 & 1 & 1 & 0 & 0 & 5 & 1 \\
\hline 21. Norfolk Island (Aust.) & 1 & 2 & 2 & 2 & 2 & 0 & 0 & 9 & 2 \\
\hline 22. Pitcairn Islands (U.K.) & 0 & 0 & 0 & 0 & 1 & 0 & 5 & 6 & 1 \\
\hline 23. Puerto Rico (U.S.) & 5 & 5 & 5 & 2 & 3 & 2 & 5 & 27 & 5 \\
\hline 24. Reunion (Fr.) & 2 & 5 & 4 & 1 & 1 & 0 & 6 & 19 & 4 \\
\hline $\begin{array}{l}\text { 25. St. Helena, Ascension and Tristan da Cunha } \\
\text { (U.K.) }\end{array}$ & 1 & 2 & 2 & 1 & 1 & 1 & 5 & 13 & 3 \\
\hline 26. Saint Pierre and Miquelon (Fr.) & 1 & 2 & 1 & 0 & 1 & 0 & 0 & 5 & 1 \\
\hline 27. Tokelau (N.Z.) & 1 & 1 & 1 & 1 & 2 & 0 & 0 & 6 & 1 \\
\hline 28. Turks and Caicos Islands (U.K.) & 2 & 4 & 4 & 1 & 1 & 0 & 1 & 13 & 3 \\
\hline 29. United States Virgin Islands (U.S.) & 4 & 5 & 5 & 1 & 1 & 3 & 0 & 19 & 4 \\
\hline 30. Wallis and Futuna (Fr.) & 1 & 1 & 1 & 0 & 1 & 0 & 0 & 4 & 1 \\
\hline
\end{tabular}


The largest number of hotels can be found in Puerto Rico, the smallest figures are in Niue, St. Helena, American Samoa, Wallis and Futuna. The largest number of luxury hotels is in Puerto Rico, French Polynesia and Guadeloupe. This indicates a very high level of development of tourist infrastructure in these dependent states. The highest levels of tourist number are in former Netherlands Antilles (Curaçao, Sint Maarten, Bonaire, St. Eustatius and Saba), Aruba, Bermuda, US Virgin Islands, British Virgin Islands, Gibraltar, Guadeloupe, Guam, Cayman Islands, Martinique, Reunion, and Puerto Rico. Virtually the same list of countries represents the biggest revenue from the tourism industry. This confirms the fact that these territories, along with favorable climatic conditions, have a well-developed tourist infrastructure and services, and already have a significant level of popularity among tourists in the world. The lowest scores for these indicators got areas such as Niue, Tokelau, Wallis and Futuna. Despite the significant natural RTR, these areas have not yet act as famous and popular tourist destinations.

Cultural and historical potential of the country is expressed primarily in its historical heritage, as presence of unique historical objects determines the opportunities for tourism development in the country. The very familiarity with the history and historical sites is a very strong incentive tourist motive. Despite the political status, the analyzed dependent territories have a significant historical and cultural potential, characterized by a high degree of attraction for tourists from all over the world.

According to A. Bejdyk [3], cultural and historical RTR comprises six basic types of architectural and urban structures: public, industrial, religious, military buildings, garden art constructions, architectural monuments and sculptural monuments.

In our coverage of dependent territories of the world all six types of architectural structures are present. However, in this study, it was decided that assessment of cultural and historical RTR of dependent states will be carried out only in terms of three separate categories - religious buildings, military architecture (castles, forts, fortresses), and architectural monuments. The choice of these types is conditioned by the fact that they, in our opinion, are of most interest to tourists and are in great demand during excursions and tours in the territory of the countries analyzed. In addition, the historical value of the religious and military complexes is in their cognitive role as a source of historical and ideological information. Also in the study of cultural and historical complexes of dependent territories of the world the availability of museums of various purposes have been taken into account, as they are the main visiting places during various excursion routes.

The greatest value in historical and cultural potential of the dependent territories of the world, of course, occupy the architectural and natural sites included in the international list of UNESCO World Heritage Site [11]. These very objects are attracted not only by ordinary tourists, but also they are valuable objects of research. Four of the seven UNESCO World Heritage Sites, available in the analyzed dependent states are natural objects, three cultural and historical:

a) «Gough and Inaccessible Islands» in the British Overseas Territory Saint Helena, Ascension and Tristan da Cunha;

b) «Henderson Island» in the British Overseas Territory Pitcairn Islands;

c) «Pitons, cirques and remparts of Reunion Island» in the French overseas department Reunion;

d) «Lagoons of New Caledonia: Reef Diversity and Associated Ecosystems» in the special collectivity of France New Caledonia;

e) «La Fortaleza and San Juan National Historic Site in Puerto Rico» in the United States territory Commonwealth of Puerto Rico;

f) «Historic Area of Willemstad, Inner City and Harbour, Curaçao» in the territory of Country of Curaçao (former Netherlands Antilles);

g) «Historic Town of St George and Related Fortifications, Bermuda», which is the first capital of the British Overseas Territories Bermuda Islands.

The results show that the dependent territories of the world are best secured with buildings of religious architecture and museum institutions - these facilities are available in almost all the countries in question. Among the buildings of religious architecture by churches and cathedrals prevail, and among the buildings of military architecture forts are most numerous. Architectural monuments are only present on Aruba, Bermuda, Guam, Reunion, Turks and Caicos Islands and French Polynesia.

Thus, we can say that cultural and historical facilities of certain dependent territories are not diverse and represented enough that could potentially have a negative effect on the intensity of tourist flows to these countries.

In determining the integrated assessment of the RTR capacity of dependent territories of the world it was proposed to use the method of lowering the total score of assessment that allows to display a visual difference in the ease of tourist and recreational resources of a particular dependent territory in the total list. In this case, we proceeded from the fact that: 
a) the total score of 4-6 balls - the lowest RTR characteristics, which are the first category areas (integral score 1 ball);

b) total score 7-9 balls - lower middle endowment of RTR, the second category of areas (integral score of 2 balls);

c) total score of 10-15 balls - average endowment of RTR, a third category of areas (integral score of 3 balls); d) total score of 16-20 balls - medium-high endowment of RTR, the fourth category of territory (integral score of 4 balls);

d) total score of 21-30 balls - high endowment of RTR, fifth category of territories (integral score of 5 balls).

Thus, having considered the dependent territories of the world for separate indicators of RTR and summarized them in an integrated assessment, it was found that the most favorable conditions for the implementation of cultural tourism have Bermuda $(\Sigma=30, \mathrm{I}=5)$. Also, high total scores of RTR and integrated assessment of 5 balls received the following dependencies: former Netherlands Antilles (Curaçao, Sint Maarten, Bonaire, St. Eustatius and Saba), Aruba, Guadeloupe, Puerto Rico, located in the Caribbean. In addition to the estimated figures, these countries also have beautiful beaches, allowing to develop here both cultural tourism and bathing-beach tourism and resort leisure. In particular, the Bermuda has all the examined types of architectural and historical monuments, including the properties inscribed on the UNESCO list. Military architecture and museums are the most diverse facilities in Bermuda. With regard to Aruba, it has the largest number of buildings of religious architecture and a large diversity of museums. In Guadeloupe numerous buildings of military architecture and a significant selection of museum institutions attract tourists. Consequently, these areas are the most favorable for the development of cultural tourism in the dependent territories of the world. All these countries are already major tourist centers of the world and attract many tourists. These areas have a favorable geographical position (in particular, the majority are located in the Caribbean, one of the major tourist destinations in the world), resulting in excellent climatic conditions that allow these countries to be visited for most of the year. This is a very convenient factor, especially for tourists from Europe and America. All these countries are islands or archipelagos that allow to develop beach tourism in their territories.

Territory of the British and US Virgin Islands, the Cayman Islands and Martinique in the Caribbean; Reunion in the Indian Ocean and the islands of French Polynesia, Guam, New Caledonia in the Pacific have good RTR. These dependent states received integral rating of 4 balls. Almost all of them are developed centers of tourist industry. They attract tourists from all over the world thanks to their climate, socioeconomic, cultural and historic resources that contribute to the development of beach, medical and health and cognitive forms of tourism.

Areas that have received integral rating of 3 balls also have prospects for development of historical and cultural, educational, bathing-beach and recreational tourism. These are the cities of Gibraltar, Ceuta and Melilla, St. Helena, Turks and Caicos, and the region of French Guiana. There are lagging behind the group leaders in the individual parameters of RTR, which nonetheless may be in a relatively short period of time to be overcome through the development of hotel base, the creation of artificial attractions (museums, tourist centers), and more active promotion of these areas in the list of interest for visit. For French Guiana and the Saint Helena extreme tourism seems to be a very promising direction.

Low integrated assessment of 2 balls got the Cook Islands, Anguilla, Montserrat, Norfolk Island. This is due to underdeveloped hospitality industry, the lack of interesting sights, historical monuments. But, nevertheless, they are promising in terms of tourism development. Especially Island of Anguilla is located in the Caribbean Sea and has the potential for the development of the bathing-beach type of tourism. Territory of Norfolk Islands, Montserrat, and the Cook Island has a unique nature, attractive to tourists.

Some dependent territories received the lowest integral score (1) when assessing their RTR. These are the areas such as Wallis and Futuna, Niue, American Samoa, Tokelau, Pitcairn Islands in the Pacific, as well as Saint Pierre and Miquelon and the Falkland Islands in America. All of them are quite remote from the world tourist flows, do not possess the necessary transport and hospitality infrastructure, attractions. It is worth noting that our results are broadly in line with the results obtained for some of the territories by other authors $[6,8]$. But it is here where wilderness and primary natural and geographical conditions are preserved. And it must be said that in the future it can become a major factor in these countries attractiveness for tourists from around the world.

Thus, on the ground of the methodology of point-based characteristics of the socio-economic RTR of certain dependent territories worldwide, five groups of countries in terms of favourableness of development and implementation of tourist activity are identified. It is important to note that only the most basic social and economic resources of the 
dependent territories of the world, which provide an immediate opportunity for further development of tourism and recreational services have been chosen for the assessment. For a more objective picture natural and other economic and social components of the RTR have to be also taken into account. Nevertheless, the results provide a representative overall basic characteristic of RTR of dependent states and territories worldwide, which makes the developed methodology verifiable also for other similar entities of the political map of the world.

\section{References:}

1. Afanasyev, O. E. Brand as the Factor of Formation of Tourist Image of the Country / In compilation : Branding of Territories. International and domestic experience. 425. Voronezh. : Voronezh Chamber of Commerce of the Voronezh region, 2010. Pp. 94-96.

2. Afanasyev, O. E. The Political Space of the Modern World: A Handbook. M. : Flint; Science, 2015. $168 \mathrm{p}$.

3. Beidyk, O. O. Recreational and Tourist Resources of Ukraine: Methodology and Methods of Analysis, Terminology, Zoning. Monography. K. : CWD «Kievskiy universitet», 2001. $395 \mathrm{p}$.

4. Blij, H. J., Muller, P. O. Geography: Realms, Regions, and Concepts. Hoboken, NJ: John Wiley and Sons, 2010. $694 \mathrm{p}$.
5. Countries of the World Today: e-mail Reference Service ITAR-TASS. URL: http://www.sms-tass.ru (date of access: 10.11.2015).

6. Gushchina, M. V. Socio-economical Preconditions for Tourism Development in Oceania // Proceedings of the 1st Annual International Conference on Tourism and Hospitality research (THoR 2012). Singapore: GSTF, 2012. Pp. 52-54.

7. Nikolaenko, T. V., Nikolaenko D.V. History and Regional Characteristics of World Tourism. Kharkov: Factor, 1998. $267 \mathrm{p}$.

8. Sazykin, A. M., Gushina M.V. Estimation of Recreational Potential of Oceania // Basic Research, 2015. № 2-23. Pp. 5149-5155.

9. The World Factbook Central Intelligence Agency. URL: https://www.cia.gov/library/publications/the-worldfactbook/index.html (date of access: 10.11.2015).

10. World DataBank: The World Bank: Official Website. URL: http://databank.worldbank.org (date of access: 10.11.2015).

11. World Heritage Centre of UNESCO: Official Website. URL: http://whc.unesco.org/en (date of access: 10.11.2015).

12. World Travel \& Tourism Council: Official Website. URL: http://www.wttc.org (date of access: 11.11.2015). 